\title{
RATE OF ACTION OF SCHISTOSOMICIDES IN MICE INFECTED WITH SCHISTOSOMA MANSONI
}

\section{Naftale Katz' ${ }^{1}$, Emmanuel Pinto Dias $\dagger$, Cecília Pereira de Souza1, John I. Bruce ${ }^{2}$, Gerald C. Coles 3}

\begin{abstract}
Mice infected with adult Schistosoma mansoni were dosed with a single oral dose of 125 or $250 \mathrm{mg} / \mathrm{kg}$ oltipraz, 50 or $100 \mathrm{mg} / \mathrm{kg}$ oxamniquine, or 200 or $400 \mathrm{mg} / \mathrm{kg}$ praziquantel. The mortality rate of worms and oogram changes were determined between 1 and 16 weeks after dosing. The time required between dosing and postmortem to obtain maximum effectiveness was 1 week for praziquantel, 2 weeks for oxamniquine and 8 weeks for oltipraz. Changes in oograms persisted throughout most of the experiment, although relapse has been observed at the 4th week on.
\end{abstract}

Key-words: Schistosoma mansoni. Schistosomicides. Worm mortality.

The speed at which drugs affect parasitic helminths varies widely. Nematodes such as Haemonchus contortus which live in the intestinal tract can be removed within 1 hour, as paralysis causes the worms to lose their hold and they are swept away ${ }^{2}$. By contrast, schistosomes which live in the blood vessels die more slowly, and Bueding et al have reported that oltipraz did not exert its maximum effect on adult Schistosoma mansoni until 8 weeks after dosing 3 .

To determine whether drug resistance has developed in isolates from treated uncured patients, experiments on mice were chosen 5 . This is a time consuming as snails must be infected and worms allowed to mature in mice. If the period between dosing and postmortem could be reduced the total time for the experiment would be shorter. On the other hand, examination of mice must be performed when the full activity of the schistosomicides on the worms can be demonstrated. In the present work we report the mortality rates of $S$. mansoni worms and oogram changes found in mice between one and sixteen weeks after dosing with three different schistosomicides.

\section{MATERIAL AND METHODS}

The LE strain of $S$. mansoni which has been laboratory maintained for about 20 years, was used to infect Biomphalaria glabrata. Cercariae collected

1. Centro de Pesquisa "René Rachou"/FIOCRUZ.

2. Center for Tropical Diseases, University of Lowell.

3. Department of Zoology, University of Massachusetts.

Correspondence to: Dr. Naftale Katz. Centro de Pesquisas "René Rachou"/FIOCRUZ. CP: 1743. 30190 Belo Horizonte, MG, Brasil.

+ Deceased on 10/23/89

Recebido para publicação em 11/11/89. within 50 days after exposure of snails were used to infect Swiss outbred strain male mice by subcutaneous injection on the back with 100 cercariae each. Forty five days after infection mice were left untreated or treated with a single oral dose of 125 or $250 \mathrm{mg} / \mathrm{kg}$ oltipraz, 50 or $100 \mathrm{mg} / \mathrm{kg}$ ox amniquine or 200 or 400 $\mathrm{mg} / \mathrm{kg}$ praziquantel suspended in $1 \%$ agar solution. At $1,2,4,8$ and 16 weeks after treatment mice were killed by cervical dislocation, and after perfusion of the mesenteric and portal veins the numbers of living and dead worms were counted and alterations in the oogram from intestinal fragments of the mice determined $^{6}$.

\section{RESULTS}

The percentage of dead worms present are shown in Figures 1 and 2. Changes in oograms are shown in Tables 1,2 and 3. The results indicate that praziquantel and oxamniquine act relatively quickly but worms continue to die for at least 8 weeks after treatment with oltipraz. Changes in oograms persisted throughout most of the experiment, but relapse can be detected at the 4 th week on, with the drugs used.

\section{DISCUSSION}

From a knowledge of the mechanism of action of praziquantel $^{1}$ it would be expected that death of worms after treatment would be rapid. The data confirm this conclusion and indicate that killing of mice within one week of dosing is satisfactory to determine the activity of praziquantel. Oxamniquine acts quite differently to praziquantel, probably by being activated, binding to DNA and preventing synthesis of RNA ${ }^{4}$. This drug also acts relatively rapidly and post mortem of mice 2 weeks after dosing is sufficient to show full efficacy of the drug. Two weeks 
Katz N, Dias EP, Souza CP, Bruce JI, Coles GC. Rate of action of schistosomicides in mice infected with Schistosoma mansoni. Revista da Sociedade Brasileira de Medicina Tropical 22: 183-186, Out-Dez, 1989.

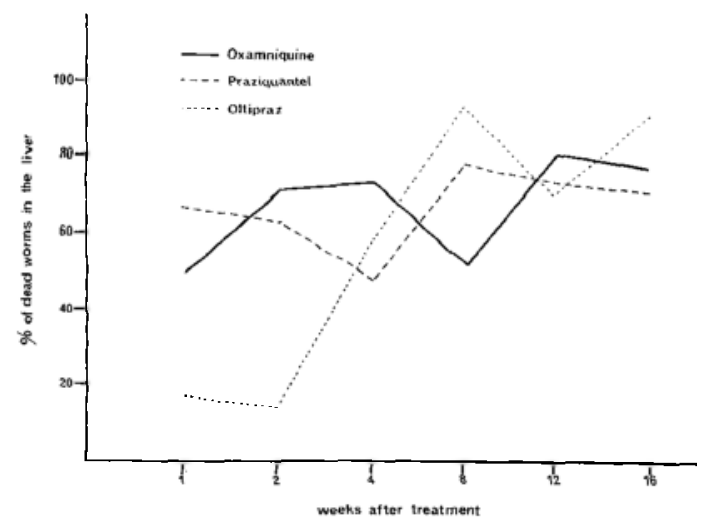

Figure 1-Mortality of Schistosoma mansoni worms in . mice experimentally infected and treated with single oral doses of oxamniquine $(50 \mathrm{mg} / \mathrm{kg})$, praziquantel $(200 \mathrm{mg} / \mathrm{kg})$ or oltipraz $(125 \mathrm{mg} / \mathrm{kg})$.

between dosing and postmortem and counting numbers of live worms is thus the optimal period for detection of strains of drug resistant schistosomes.

By contrast the full efficacy of oltipraz is slow to appear, in agreement with the observations of Bueding and coworkers ${ }^{3}$, and mice must be left for 8 weeks to

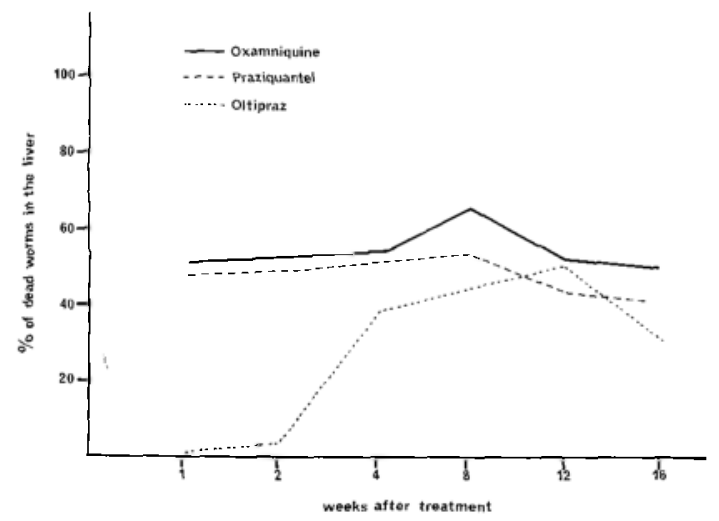

Figure 2 -Mortality of Schistosoma mansoni worms in mice experimentally infected and tretated with single oral doses of oxamniquine $(100 \mathrm{mg} / \mathrm{kg})$, praziquantel $(400 \mathrm{mg} / \mathrm{kg})$ or oltipraz $(250 \mathrm{mg} / \mathrm{kg})$.

observe the maximum effect. Although oltipraz has been reported to affect glutathione levels in the worms ${ }^{3}$ and the maximum drug concentrations are present within worms at 18 hours of dosing 3 it is not clear why it should take so long for oltipraz to take its full effect.

Table 1 - Activity of praziquantel on mice experimentally infected with Schistosoma mansoni (LE strain) examined at different time after treatment.

\begin{tabular}{ccccccccc}
\hline $\begin{array}{c}\text { Drug and } \\
\text { Dose } \\
(\mathrm{mg} / \mathrm{kg})\end{array}$ & $\begin{array}{c}\text { Weeks } \\
\text { after } \\
\text { treatment }\end{array}$ & $\begin{array}{c}\text { Number of } \\
\text { mice }\end{array}$ & $\begin{array}{c}\text { Mean } \\
\text { Treated Examined of worms } \\
\text { number }\end{array}$ & $\begin{array}{c}\text { Distribution of worms } \\
\text { Mesenteric } \\
\text { vessels }\end{array}$ & $\begin{array}{c}\text { Dead worms } \\
\text { Liver } \\
\text { in the liver } \\
(\%)\end{array}$ & $\begin{array}{c}\text { Oogram } \\
\text { alteration } \\
(\%)\end{array}$ \\
& 1 & 10 & 10 & 32.7 & 29.1 & 70.9 & 66.7 & 100.0 \\
Praziquantel & 2 & 10 & 4 & 34.0 & 19.1 & 80.9 & 64.7 & 100.0 \\
& 4 & 10 & 7 & 30.6 & 41.1 & 58.9 & 48.6 & 42.9 \\
400 & 8 & 10 & 4 & 26.0 & 16.3 & 83.7 & 79.8 & 75.0 \\
& 12 & 10 & 6 & 19.5 & 22.2 & 77.8 & 74.4 & 66.7 \\
& 16 & 10 & 5 & 24.2 & 20.7 & 79.3 & 71.1 & 80.0 \\
& Control & & 10 & 33.7 & 92.0 & 8.0 & 0.0 & 0.0 \\
\hline & 1 & 10 & 9 & 27.0 & 40.3 & 59.7 & 47.2 & 62.5 \\
Praziquantel & 2 & 11 & 11 & 23.3 & 36.7 & 63.3 & 53.7 & 54.5 \\
& 4 & 9 & 9 & 25.3 & 32.5 & 67.5 & 53.9 & 44.4 \\
& 8 & 10 & 7 & 20.3 & 33.1 & 66.9 & 54.2 & 14.3 \\
& 12 & 11 & 6 & 20.8 & 46.4 & 53.6 & 44.0 & 33.3 \\
& 16 & 10 & 5 & 16.6 & 41.0 & 59.0 & 42.2 & 40.0 \\
& Control & & 10 & 33.7 & 92.0 & 8.0 & 0.0 & 0.0 \\
\hline
\end{tabular}


Katz N, Dias EP, Souza CP, Bruce JI, Coles GC. Rate of action of schistosomicides in mice infected with Schistosoma mansoni. Revista da Sociedade Brasileira de Medicina Tropical 22: 183-18,, Out-Dez, 1989.

Table 2 - Activity of oxamniquine on mice experimentally infected with Schistosoma mansoni (LE strain) examined at different time after treatment.

\begin{tabular}{|c|c|c|c|c|c|c|c|c|}
\hline $\begin{array}{c}\text { Drug and } \\
\text { Dose } \\
(\mathrm{mg} / \mathrm{kg})\end{array}$ & $\begin{array}{l}\text { Weeks } \\
\text { after } \\
\text { treatment }\end{array}$ & \multicolumn{2}{|c|}{$\begin{array}{l}\text { Number of } \\
\text { mice } \\
\text { Treated Examined }\end{array}$} & \multirow{2}{*}{$\begin{array}{c}\begin{array}{c}\text { Mean } \\
\text { number } \\
\text { of worms }\end{array} \\
41.8\end{array}$} & $\begin{array}{l}\text { Distribution } \\
\text { Mesenteric } \\
\text { vessels }\end{array}$ & $\begin{array}{l}\text { worms } \\
\text { Liver }\end{array}$ & $\begin{array}{l}\text { Dead worms } \\
\text { in the liver } \\
(\%)\end{array}$ & $\begin{array}{c}\text { Oogram } \\
\text { alteration } \\
(\%)\end{array}$ \\
\hline \multirow{4}{*}{ Oxamniquine } & 1 & 10 & 8 & & 26.9 & 73.1 & 50.0 & 87.5 \\
\hline & 2 & 9 & 7 & 40.7 & 20.0 & 80.9 & 70.5 & 100.0 \\
\hline & 4 & 10 & 9 & 24.4 & 20.0 & 80.0 & 73.2 & 66.7 \\
\hline & 8 & 10 & 8 & 23.9 & 37.7 & 62.3 & 54.5 & 37.5 \\
\hline \multirow[t]{5}{*}{100} & 12 & 10 & 8 & 23.3 & 11.0 & 89.0 & 80.4 & 57.2 \\
\hline & 16 & 9 & 5 & 24.2 & 13.9 & 86.1 & 77.9 & 80.0 \\
\hline & Control & & 11 & 28.0 & 78.6 & 21.4 & 0.0 & 0.0 \\
\hline & 1 & 10 & 8 & 36.5 & 35.3 & 64.7 & 51.4 & 62.5 \\
\hline & 2 & 9 & 8 & 28.5 & 37.3 & 62.7 & 52.2 & 62.5 \\
\hline \multirow[t]{2}{*}{ Oxamniquine } & 4 & 10 & 7 & 36.9 & 33.3 & 66.7 & 53.9 & 85.7 \\
\hline & 8 & 10 & 8 & 35.5 & 29.6 & 70.4 & 65.5 & 25.0 \\
\hline \multirow[t]{3}{*}{50} & 12 & 10 & 7 & 33.0 & 35.5 & 64.5 & 52.8 & 42.9 \\
\hline & 16 & 7 & 2 & 29.0 & 39.7 & 60.3 & 51.7 & 100.0 \\
\hline & Control & & 11 & 28.0 & 78.6 & 21.4 & 0.0 & 0.0 \\
\hline
\end{tabular}

Table 3 - Activity of oltipraz on mice experimentally infected with Schistosoma mansoni (LE strain) examined at different time after treatment.

\begin{tabular}{|c|c|c|c|c|c|c|c|c|}
\hline \multirow{2}{*}{$\begin{array}{c}\text { Drug and } \\
\text { Dose } \\
(\mathrm{mg} / \mathrm{kg})\end{array}$} & \multirow{2}{*}{$\begin{array}{l}\text { Weeks } \\
\text { after } \\
\text { treatment }\end{array}$} & \multirow{2}{*}{\multicolumn{2}{|c|}{$\begin{array}{c}\text { Number of } \\
\text { mice } \\
\text { Treated Examined }\end{array}$}} & \multirow{2}{*}{$\begin{array}{l}\text { Mean } \\
\text { number } \\
\text { of worms }\end{array}$} & \multicolumn{2}{|c|}{ Distribution of worms } & \multirow{2}{*}{$\begin{array}{c}\text { Dead worms } \\
\text { in the Liver } \\
(\%)\end{array}$} & \multirow{2}{*}{$\begin{array}{c}\text { Oogram } \\
\text { alteration } \\
(\%)\end{array}$} \\
\hline & & & & & $\begin{array}{l}\text { Mesenteric } \\
\text { vessels }\end{array}$ & Liver & & \\
\hline \multirow{4}{*}{ Oltipraz } & 1 & 10 & 8 & 36.8 & 50.7 & 49.3 & 18.7 & 75.0 \\
\hline & 2 & 10 & 8 & 33.9 & 63.8 & 80.9 & 18.5 & 37.5 \\
\hline & 4 & 10 & 10 & 23.7 & 22.8 & 58.9 & 59.1 & 80.0 \\
\hline & 8 & 9 & 7 & 16.5 & 3.0 & 83.7 & 87.9 & 100.0 \\
\hline \multirow[t]{5}{*}{250} & 12 & 10 & 10 & 13.3 & 18.8 & 77.8 & 72.9 & 60.0 \\
\hline & 16 & 7 & 5 & 10.2 & 9.8 & 79.3 & 90.2 & 100.0 \\
\hline & Control & & 10 & 19.2 & 94.3 & 8.0 & 0.0 & 0.0 \\
\hline & 1 & 10 & 10 & 25.3 & 83.0 & 17.0 & 1.6 & 10.0 \\
\hline & 2 & 10 & 10 & 38.2 & 85.6 & 14.4 & 3.9 & 20.0 \\
\hline \multirow[t]{2}{*}{ Oltipraz } & 4 & 10 & 8 & 17.8 & 47.2 & 52.8 & 38.7 & 25.0 \\
\hline & 8 & 10 & 10 & 12.3 & 35.8 & 64.2 & 45.5 & 30.0 \\
\hline \multirow[t]{3}{*}{125} & 12 & 10 & 7 & 11.0 & 30.3 & 69.7 & 51.5 & 66.7 \\
\hline & 16 & 10 & 5 & 12.0 & 56.7 & 43.3 & 31.7 & 60.0 \\
\hline & Control & & 10 & 19.2 & 94.3 & 5.7 & 0.0 & 0.0 \\
\hline
\end{tabular}


Katz N, Dias EP, Souza CP, Bruce JI, Coles GC. Rate of action of schistosomicides in mice infected with Schistosoma mansoni. Revista da Sociedade Brasileira de Medicina Tropical 22: 183-186, Out-Dez, 1989.

\section{RESUMO}

Camundongos infectados experimentalmente com Schistosoma mansoni foram tratados por via oral com dose única de 125 ou $250 \mathrm{mg} / \mathrm{kg}$ de oltipraz, 50 ou $100 \mathrm{mg} / \mathrm{kg}$ de oxamniquine, e $200 \mathrm{ou} 400 \mathrm{mg} / \mathrm{kg}$ de praziquantel. O número de vermes e alteração do oograma foram determinados entre a 1a e 16a semanas após o tratamento. $O$ tempo necessário para observar o máximo de atividade da droga foi de 1 semana para o praziquantel, 2 semanas para o oxamniquine e 8 semanas para o oltipraz. Alterações do oograma persistiram durante o periodo de observação, embora recidiva tenha sido detectada, já na 4a semana, com as drogas utilizadas.

Palavras-chaves: Schistosoma mansoni. Esquissomicidas. Mortalidade de vermes.

\section{REFERENCES}

1. Andrews P. Praziquantel: mechanisms of anti-schistosomal activity. Pharmacology and Therapeutics 29:129$156,1985$.

2. Briscoe MG, Coles GC. The speed of action of anthelmintics. Veterinary Record 106:58, 1980.

3. Bueding E, Dolan P, Leroy JP. The antischistosomal activity of oltipraz. Research Communications in Chemical Pathology and Pharmacology 37: 293-303, 1982.

4. Cioli D, Pica-Mattoccia L, Rosenberg S, Archer S. Evidence for the mode of antischistosomal action of hycanthone. Life Sciences 37:161-167, 1985.

5. Katz N, Dias EP, Araujo N, Souza CP. Estudo de uma cepa humana de Schistosoma mansoni resistente a agentes esquistossomicidas. Revista da Sociedade Brasileira de Medicina Tropical 7:381-387, 1973.

6. Pellegrino J, Katz N. Chemotherapy of Schistosoma mansoni. In: Dawes B (ed) Advances in Parasitology, London, Academic Press, p. 233-290, 1968. 